\title{
PROFESIONALISME GURU DALAM PENGGUNAAN METODE DISCOVERY UNTUK MENINGKATKAN HASIL BELAJAR IPA DI KELAS IV SEKOLAH DASAR NEGERI 28 AIR TAWAR TIMUR KOTA PADANG
}

\author{
Oleh : Syamsu Arlis \\ Email: syamsu_arlis@yahoo.com \\ FIP Universitas Negeri Padang
}

\begin{abstract}
The purpose of this research is to improve the students learn of result in Natural Science through discovery approach of the IV grade students of Elementary School in Air Tawar, Padang. This research is a Classroom Action which consist of two meetings in two cycles. This research utilizes four steps of actions, are planning, action, observation, and reflection. The result of the study shows that the students learn of result in Natural Science experiencing of improvement and the improvement of students' achievement can be observed from the affective, psychomotor, and cognitive.
\end{abstract}

Keywords: discovery, hasil belajar, ilmu pengetahuan alam, siswa SD.

\section{PENDAHULUAN}

Pembangunan menyeluruh bidang pendidikan merupakan salah satu upaya untuk meningkatkan Sumber Daya Manusia (SDM) yang berkualitas. Pada dasarnya upaya tersebut bertujuan untuk menyamakan gerak langkah bangsa Indonesia dalam mencapai masyarakat adil dan makmur tanpa kehilangan identitasnya. Di mana hasil pembangunan yang seperti ini tidak mudah untuk dicapai, perlu usaha terpadu dari segala pihak, terutama dalam usaha untuk memenuhi sarana dan prasarana pendidikan. Hal ini dimaksudkan agar pembangunan tersebut dilaksanakan oleh tenaga-tenaga berkualitas baik dari segi fisik maupun non fisik.

Pembelajaran Ilmu Pengetahuan Alam (IPA) menuntut siswa aktif dalam belajar. Sebab pelajaran IPA merupakan serangkaian kegiatan proses ilmiah antara lain penyelidikan (eksperimen), penyusunan dan pengkajian gagasan serta konsep.

Untuk mencapai tujuan pembelajaran IPA perlu dibekali dengan berbagai kompetensi yang memadai sehingga bisa menjadi siswa yang aktif, kreatif dan mampu mempelajari alam sekitarnya. Kemampuan yang diharapkan dapat dimiliki oleh siswa tersebut, sesuai dengan yang dijelaskan dalam kurikulum berbasis kompetensi (2004:3) tentang pembelajaran IPA sebagai berikut : "IPA berkaitan dengan cara mengetahui tentang alam secara sistematis, sehingga IPA bukan hanya sekedar penguasaan keterampilan, pengetahuan yang berupa fakta-fakta, konsep-konsep atau prinsip saja tetapi juga merupakan proses penemuan".

Pembelajaran IPA menekankan pada pemberian pengalaman langsung dari kegiatan praktis untuk mengembangkan kompetensi agar siswa dapat memahami alam sekitar secara ilmiah. Pembelajaran IPA di arahkan untuk mencari tahu dan berbuat sehingga dapat membantu siswa untuk memperoleh pengalaman yang lebih mendalam tentang alam sekitar. Melalui pembelajaran IPA di Sekolah Dasar (SD), siswa berlatih berfikir memahami konsep dari pengamatan dan 
percobaan, agar pembelajaran bermakna bagi siswa dan hasil belajar akan meningkat.

Kenyataan yang ditemukan di SD Negeri 28 Air Tawar Timur Kecamatan Padang Utara, pada kelas IV semester 1 tahun ajaran 2009/2010 menunjukkan bahwa hasil belajar IPA siswa tersebut belum sesuai dengan yang diharapkan, karena $65 \%$ masih berada di bawah SKM, standar ketuntasan minimal SD 28 Air Tawar Timur adalah 7. Hal ini disebabkan oleh pembelajaran IPA masih diajarkan dengan menggunakan metode ceramah sebagai metode utama dalam pembelajaran, pada umumnya siswa ditugaskan membaca dan menjawab soal yang ada di buku teks. Siswa hanya bisa mengingat dan sangat sulit bagi siswa untuk memiliki keterampilan yang dapat digunakan dalam kehidupan, dan menyelesaikan masalah yang dihadapi, sehingga tujuan pembelajaran IPA yang sesuai dengan kompetensi yang diharapkan kurikulum sangat sulit untuk dicapai. Dari itu dituntut guru dapat memilih metode yang sesuai dengan materi yang diajarkan. Salah satu metode yang dapat digunakan dalam pembelajaran IPA adalah metode discovery. Metode discovery menurut Amien (1987:126) adalah

Cara penyajian yang melibatkan siswa dalam proses-proses mental dalam penemuannya terhadap suatu materi, sehingga dalam pembelajaran discovery siswa mampu mengamati, menggolong-golongkan, membuat dugaan, menjelaskan, mengukur dan menarik kesimpulan dalam usaha memahami suatu materi. Diharapkan juga siswa dapat memperoleh pengalaman langsung untuk mengembangkan kompeten-sinya agar mampu menjelajahi dan memahami alam sekitar secara ilmiah.

Berdasarkan pendapat yang telah dikemukakan di atas, maka dapat penulis simpulkan bahwa metode discovery adalah cara penyajian yang melibatkan siswa dalam menemukan sesuatu sehingga siswa memperoleh pengalaman langsung pembelajaran bermakna dan hasil belajar sesuai dengan yang diharapkan.

Berdasarkan uraian di atas, maka tujuan dari penelitan ini adalah untuk mendeskripsikan penggunaan metode discovery untuk meningkatkan hasil belajar IPA di kelas IV SD Negeri 28 Air Tawar Timur.

\section{Metode Discovery dalam Pembelajaran di SD}

Metode discovery adalah suatu metode dalam pembelajaran yang memerlukan proses mental dan mengarahkan siswa untuk mendapatkan suatu kesimpulan dari materi pelajarannya, sehingga pembelajaran bermakna dan hasil pembelajaran sesuai dengan yang diharapkan. Guru hanya sebagai fasilitator dan motivator dalam mengarahkan serta membimbing siswa untuk menemukan sesuatu yang dapat mereka gunakan serta menerapkannya dalam kehidupannya sehari-hari. Carin (1985:126) mengemukakan metode discovery adalah: "Suatu kegiatan atau pelajaran yang dirancang sedemikian rupa sehingga siswa dapat menemukan konsepkonsep dan prinsip-prinsip melalui proses mentalnya sendiri”.

Menurut Roestiyah (2001:20) keunggulan metode discovery adalah (a) Mampu membantu siswa untuk mengembangkan, memperbanyak kesiapan, serta panguasaan keterampilan dalam proses kognitif atau pengenalan siswa, (b) Siswa memperoleh pengetahuan yang bersifat sangat pribadi atau individual sehingga dapat kokoh atau mendalam tertinggal dalam jiwa siswa tersebut, (c) Dapat meningkatkan kegairahan belajar para siswa.

\section{Hasil Belajar}

Hasil belajar merupakan tolak ukur yang digunakan untuk menentukan tingkat keberhasilan siswa dalam memahami konsep pembelajaran. Apabila sudah terjadi perubahan tingkah laku seseorang, maka orang itu telah bisa dikatakan 
akan berhasil dalam belajar, sebagaimana yang dikemukakan Oemar (2005:2) "Hasil belajar adalah tingkah laku yang timbul, misalnya dari tidak tahu menjadi tahu, timbulnya pertanyaan baru, perubahan dalam tahap kebiasaan keterampilan, kesanggupan menghargai, perkembangan sikap sosial, emosional, dan perubahan jasmani”.

\section{Pembelajaran IPA di Sekolah Dasar}

Abruscato (dalam Maslichah, 2006:7) mengatakan "IPA merupakan pengetahuan yang diperoleh melalui serangkaian proses yang sistematis untuk mengungkap segala sesuatu yang berkaitan dengan alam semesta". Selain itu Iskandar (1996:2) juga mengatakan bahwa "IPA adalah salah satu pengetahuan yang dimiliki manusia melalui proses observasi dan bereksperimen. Dengan demikian IPA tidak ada dengan sendirinya akan tetapi IPA hadir lewat pemikiran manusia yang berkembang dan diperoleh dengan cara terkontrol".

Pendidikan IPA menekankan pada pemberian pengalaman langsung dan kegiatan praktis untuk mengembangkan kompetensi agar siswa mampu menjelajahi dan memahami alam sekitar secara ilmiah.

\section{Penerapan Metode Discovery Dalam Pembelajaran IPA Di SD}

Ada lima tahap yang harus ditempuh dalam metode discovery menurut Rohani (2004:39) yaitu: (a) Perumusan masalah, (b) Penetapan jawaban sementara, (c) Siswa mencari informasi, data, fakta untuk menguji hipotesis, (d) Menarik kesimpulan, (e) Aplikasi kesimpulan atau generalisasi dalam situasi baru.
Sehubungan dengan hal di atas maka langkah-langkah metode discovery yang akan penulis terapkan dalam penelitian ini adalah menurut Mulyasa (2005:110) adalah sebagai berikut: (1) Adanya masalah yang akan dicapai, (2) Sesuai dengan tingkat perkembangan kognitif peserta didik, (3) Konsep atau prinsip yang harus ditemukan oleh peserta didik melalui kegiatan tersebut perlu dikemukakan dan ditulis secara jelas, (4) Harus tersedia alat dan bahan yang diperlukan, (5) Susunan kelas diatur sedemikian rupa sehingga memudahkan terlibatnya arus bebas pikiran peserta didik dalam kegiatan belajar mengajar, (6) Guru harus memberikan kesempatan kepada peserta didik untuk mengumpulkan data, dan (7) Guru harus memberikan jawaban dengan tepat dengan data serta informasi yang diperlukan peserta didik.

\section{METODOLOGI PENELITIAN}

\section{Jenis Penelitian}

Penelitian ini merupakan "classroom action research" (penelitian tindakan kelas) yang dilakukan untuk meningkatkan pemahaman konsep dan hasil belajar IPA siswa melalui pendekatan discovery. Penelitian ini dilakukan secara kolaboratif antara peneliti dan guru kelas.

Penelitian tindakan kelas yang dilaksanakan menggunakan model siklus yang dikembangkan oleh Kemmis dan Taggart (1990:11) yang mempunyai 4 tahap yaitu perencanaan, tindakan, pengamatan, dan refleksi. Penelitian ini dilaksanakan dalam 2 siklus yaitu siklus I dan siklus II. Setiap siklus dilaksanakan 2 kali pertemuan. Pada akhir setiap siklus dilakukan tes hasil belajar. Untuk lebih jelasnya daapat dilihat dalam bagan berikut: 


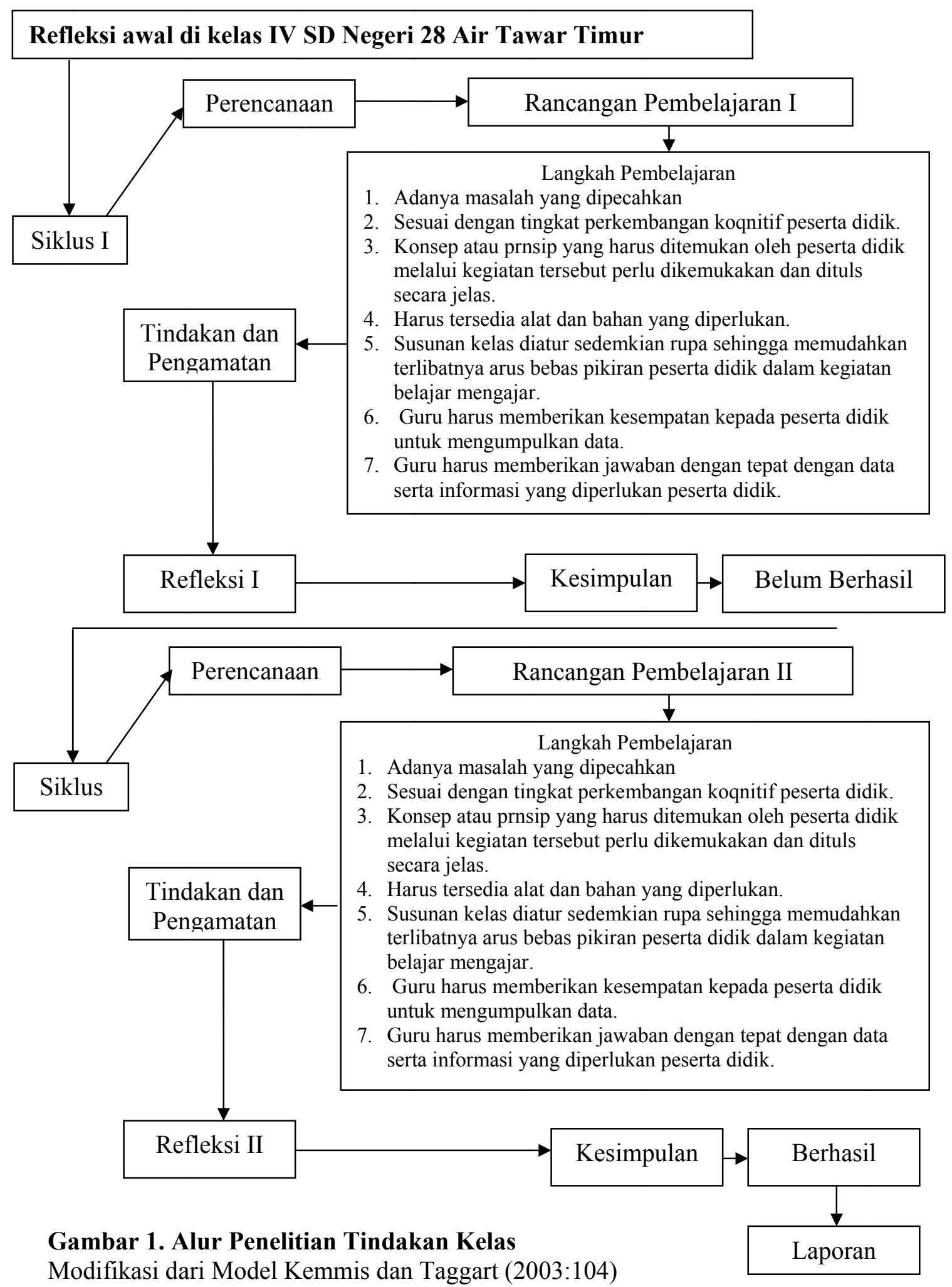


Pelaksanaan penelitian tindakan kelas dapat dilakukan dengan lima tahap yaitu :

1. Refleksi Awal, dimulai dengan observasi awal terhadap pembelajaran IPA di keas IV. Hal ini dilakukan untuk mengamati permasalahan yang dihadapi guru dan siswa berkaitan dengan pembelajaran IPA d kelas IV SD.

2. Tahap perencanaan, yaitu membuat rencana tindakan yang akan dilakukan yang berhubungan dengan pembelajaran.

3. Tahap pelaksanaan, yitu implementasi dari perencanaan.

4. Tahap pengamatan, yaitu melakukan pengamatan terhadap efek dari tindakan yang dilakukan dengan menggunakan instrumen dan catatan lapangan yang telah disediakan.

5. Tahap refleksi, dimana hasil observasi kelas, rekaman data, maupun catatan lapangan dan berbagai temuan dibawa ke forum refleksi untuk dianalisis sebagai dasar perencanaan pelaksanakan tindakan pada siklus berikutnya.

\section{Lokasi penelitian}

Penelitian tindakan kelas ini dilakukan di SD Negeri 28 Air Tawar Timur yang terletak di jalan Pinang Sori 1 kecamatan Padang Utara.

\section{Sumber data}

Sumber data penelitian adalah proses kegiatan pembelajaran IPA dengan metode discovery yang meliputi: perencanaan pembelajaran, pelaksanaan pembelajaran, kegiatan evaluasi pembelajaran, perilaku guru dan siswa sewaktu proses pembelajaran. Data diperoleh dari subjek terteliti, yakni guru dan siswa kelas IV SD Negeri 28 Air Tawar Timur. Data dari guru diperoleh melalui observasi dan wawancara awal tidak terstruktur sebelum tindakan dilaksanakan untuk mendapatkan permasalahan yang dihadapi. Selanjutnya, peneliti bersama peneliti sejawat mengamati kegiatan guru selama proses pembelajaran berlangsung dan selama tindakan dilaksanakan dengan menggunakan catatan lapangan dan lembar observasi.

Data dari siswa diperoleh berdasarkan penilaian atas aspek afektif dan psikomotor serta aspek kognitif (skor hasil belajar) siswa yang dilakukan pada akhir setiap pertemuan per siklus. Hasil belajar tersebut digunakan untuk melihat peningkatan pemahaman konsep dan hasil belajar siswa setelah tindakan dilaksanakan.

\section{Teknik Pengumpulan Data}

Data penelitian ini dikumpulkan dengan menggunakan lembar observasi, hasil, tes, dan dokumentarumen yang digunakan dalam peneliti.

\section{Instrumen Penelitian}

Instrumen yang digunakan dalam penelitian berupa lembar observasi aspek afektif, lembar observasi aspek psikomotor, dan hasil tes kemampuan siswa (aspek kognitif).

\section{Analisis Data}

Data yang diperoleh dalam penelitian dianalisis dengan menggunakan teknis analisis kualitatif dan kuantitatif yang dikembangkan oleh Miles dan Huberman (dalam Kunandar, 2008:101) yakni, analisa data dimulai dengan menelaah sejak pengumpulan data sampai keseluruh data terkumpul.

\section{HASIL PENELITIAN DAN PEMBAHASAN \\ Hasil Penelitian}

\section{Siklus I (Pertemuan pertama dan kedua)}

1. Perencanaan Tindakan

Rencana tindakan dilakuan sebagai upaya untuk mengatasi permaslahan dalam pembelajaran. Rencana tindakan akan dilakukan melalui pembelajaran dengan penerapan metode discovery.

2. Pelaksanaan Tindakan

a. Adanya masalah yang akan dipecahkan. 
Pelaksanaan pembelajaran dimulai dengan siswa disuruh duduk berkelompok sesuai dengan kelompok yang telah disepakati. Kemudian siswa diajak dan dibimbing untuk merumuskan masalah dengan pertanyaan-pertanyaan melalui gambar yang telah disediakan.

b. Sesuai dengan tingkat perkem-bangan kognitif peserta didik.

Langkah pembelajaran dilanjutkan dengan menganalisa masalah yang sudah ditemukan sesuai dengan tingkat perkembangan kognitif anak.

c. Konsep atau prinsip yang harus ditemukan oleh siswa melalui kegiatan tersebut perlu dikemu-kakan dan ditulis secara jelas.

Guru menyuruh notulis dari masingmasing kelompok untuk mencatat rumusan masalah yang ada dipapan tulis. Dari rumusan masalah diatas siswa didorong untuk mencari jawaban yang tepat.

d. Tersedia alat dan bahan yang diperlukan

Pada tahap ini siswa menyediakan alat dan bahan yang digunakan dalam melakukan percobaan.

e. Susunan kelas diatur sedemikian rupa.

Pada pelaksanaan tindakan ini dimulai dengan membagi siswa menjadi delapan kelompok, dimana kelompok tersebut telah ditentukan oleh guru dimana susunannya diatur sedemikian rupa sehingga memu-dahkan terlibatnya arus bebas berfikir siswa dalam kegitan tersebut.

f. Mengumpulkan data

Mengumpulkan data akan dilakukan melalui percobaan untuk menemukan jawaban atas pertanyaan apa saja seperti apakah itu gaya dan pengaruh gaya terhadap gerak suatu benda.

Setelah siswa mendapatkan alat dan bahan percobaan, guru membagikan lembaran kerja siswa (LKS) 1,2,3, yang berisi cara kerja atau langkah-langkah percobaan dan pertanyaan yang harus dijawab siswa setelah melakukan percobaan.

Hasil pengamatan masing-masing kelompok diisikan ke dalam tabel hasil pengamatan yang ada pada LKS. Selanjutnya masing-masing kelompok menjawab pertanyaan yang ada pada LKS.

g. Berikan sedikit kesimpulan dari kegiatan tersebut.

Hasil pengamatan masing-masing kelompok diisikan ke dalam tabel hasil pengamatan yang ada pada LKS. Selanjutnya masing-masing kelompok menjawab pertanyaan yang ada pada LKS. Salah satu kelompok melaporkan hasil percobaan yang baru saja mereka lakukan ke depan kelas.

Setelah laporan setiap kelompok selesai LKS dikumpul ke depan kelas dan siswa duduk kembali pada posisi semula. Untuk lebih meyakinkan lagi guru menugaskan beberapa orang siswa secara bergiliran untuk menyebutkan dan menemutunjukkan yang benar atau masalah yang ada.

3. Pengamatan

Hasil pengamatan yang dilakukan pada siklus I adalah:

a. Penampilan guru selama proses pembelajaran berlangsung.

Hasil pengamatan penampilan guru selama proses pembelajaran berlangsung pasa siklus I memperlihatkan bahwa dalam pelaksanaan pembelajaran discovery pertemuan pertama siklus I diperoleh skor rata-rata 57\%. Jika didasarkan pada kriteria yang telah ditetapkan, skor rata-rata tersebut berada pada $<69 \%$ sehingga masuk criteria kurang baik. Berarti guru masih 
perlu menerapkan metode discovery dalam pembelajaran IPA dengan lebih baik.

b. Penampilan siswa selama proses pembelajaran berlangsung

1) Aspek penilaian afektif.

Pada pertemuan pertama siklus I, kerjasama siswa terlihat kurang dalam diskusi kelompok, kerjasama siswa dalam kelompok berlangsung seadanya, karena tidak semua anggota yang aktif dalam berdiskusi, tapi hanya 2 atau 3 orang saja yang terlihat aktif berdiskusi.

2) Aspek Penilaian Psikomotor.

Pada pertemuan pertama siklus I, siswa terlihat sudah cukup tepat dalam melakukan langkah kerja dan menggunakan alat-alat tapi masih berdasarkan instruksi guru. Siswa sudah cukup mampu membuat laporan kerja secara beruntutan atas instruksi guru, Siswa sudah mampu bekerja dalam kelompok, sebagian besar masih bersifat individu dan tidak saling membantu.

\section{Refleksi}

Ada beberapa permasalahan yang sedikit menghambat pelaksanaan pembelajaran dengan penerapan metode diskovery pada pertemuan kedua siklus I ini adalah pada tahap pengumpulan data belum terlaksana secara maksimal, dimana guru belum mampu memotivasi siswa mengumpulkan data dan menjelaskan apa yang akan dikerjakan siswa dalam mengumpul-kan data. Tahap merumuskan kesimpulan juga belum terlaksana secara maksimal, karena guru belum berhasil memotivasi siswa untuk menyampaikan pendapatnya dalam diskusi kelompok, belum berhasil mengajukan pertanyaan yang memudahkan siswa dalam membuat kesimpulan dan belum berhasil mengarahkan siswa dalam membuat kesimpulan.

Demikian juga hambatan yang dialami oleh siswa, dalam melakukan kerja kelompok, sebagian besar siswa masih terlihat belum saling membantu. Siswa juga masih belum termotovasi untuk melakukan persentasi.

Setelah siklus I selesai dilaksanakan, maka dilakukan diskusi antara peneliti dengan teman sejawat. Dapat diambil kesimpulan bahwa pelaksanaan pembelajaran dengan penerapan metode discovery pada siklus I baru dalam kategori cukup (52\%.), hasil belajar yang dicapai siswa termasuk pada kriteria belum tuntas. Dari tujuh kategori metode discovery yang msih menjadi hambatan pada pelaksnaan siklus I untuk selanjutnya diperbaiki pada siklus II.

\section{Siklus II (Pertemuan ketiga dan keempat)}

1. Perencanaan Tindakan

Rencana tindakan dilakukan sebagai upaya untuk mengatasi permasalahan dalam pembelajaran yang ditemukan pada siklus I.

2. Pelaksanaan Tindakan

a. Adanya masalah yang akan dipecahkan.

Penggunaan metode discovery dalam pembelajaran diawali dengan menyampaikan materi dan tujuan pembelajaran. Pada langkah ini guru melak-sanakan rumusan permasalahan dengan mengajukan pertanyaan tentang gambar yang dipajang di depan kelas oleh guru.

b. Sesuai dengan tingkat perkem-bangan kognitif peserta didik

Siswa dibimbing untuk menganalisa masalah secara kritis. Pembelajaran dilanjutkan dengan merumuskan hipotesa sesuai dengan tingkat perkembangan kognitif siswa. Siswa membuat jawaban sementara 
sesuai kemampuan masing-masing anak dari masalah yang dirumuskan.

c. Konsep atau prinsip yang harus ditemukan oleh siswa melalui kegiatan tersebut perlu dikemu-kakan dan ditulis secara jelas

Jawaban yang disebutkan siswa, tidak dibenarkan dan tidak juga di salahkan, guru menam-pung semua jawaban dari siswa.

d. Tersedia alat dan bahan yang diperlukan

Pada percobaan perte-muan pertama siklus II, ini siswa menyediakan alat dan bahan berupa karet mainan, lilin mainan (plastisin), pegas, balon karet, kertas dan pensil, kelereng besar dan batu.

e. Susunan kelas diatur sedemikian rupa

Susunan kelas sama seperti pada pertemuan pertama dimana siswa dibagi menjadi delapan kelompok dan tiap kelompok beranggotakan 4 dan 5 orang dimana susunan kelas diatur sedemikian rupa sehingga memudahkan peserta didik untuk bebas mengeluarkan pendapatnya dalam berdiskusi.

f. Mengumpulkan data

Pada tahap ini guru harus memberikan kesempatan kepada siswa untuk mengumpulkan data dengan melakukan percobaan. Kegiatan percobaan ini dilakukan oleh siswa secara berkelompok

Guru memperhatikan cara kerja siswa dan menugas-kan siswa mengisi lembaran LKS yang diberikan berdasarkan hasil percobaan. Semua siswa terlihat mencoba menyiapkan alat dan bahan yang sesuai dengan percobaan.

Pada langkah pengum-pulan data masing-masing kelompok dibawah bimbingan guru membuka buku paket dan LKS yang telah diberikan guru. Siswa mencatat seluruh infor-masi yang diperoleh sesuai dengan masalah yang telah dirumuskan. Langkah selanjut-nya adalah menguji hipotesa.

Siswa sibuk dalam kelompok menguji hipotesa yang mereka buat. Pada langkah ini menentukan jawaban yang dianggap diterima sesuai dengan data yang diperoleh berdasarkan pengumpulan data yang sudah dilakukan. Siswa mengkoreksi jawaban sementara yang dibuat sesuai dengan data yang ada pada LKS. Kemudian masing-masing ketua kelompok melaporkan hasil koreksi yang mereka lakukan dan kelompok lain menanggapi.

g. Berikan sedikit kesimpulan dari kegiatan tersebut.

Untuk lebih meyakinkan lagi guru menugaskan beberapa siswa secara bergiliran untuk menemutunjukkan jawaban yang benar atas masalah yang ada.

3. Pengamatan

Hasil pengamatan yang dilakukan pada siklus I adalah:

a. Penampilan guru selama proses pembelajaran berlangsung

Aktifitas guru dalam kegiatan pembelajaran pada pertemuan pertama siklus II ini secara umum berlangsung sesuai dengan rencana yang telah ditetapkan. Hasil pengamatan memperlihatkan bahwa dalam pelaksanaan pembelajaran discovery pertemuan pertama siklus II diperoleh skor rata-rata $82 \%$ sehingga masuk kriteria baik. Berarti guru masih perlu menerapkan metode discovery dalam pembelajaran IPA dengan lebih baik. 
b. Penampilan siswa selama proses pembelajaran berlangsung

1) Aspek penilaian afektif

Pada pertemuan pertama

siklus II, siswa terlihat sudah semakin memiliki perhatian terhadap pelajaran.

Kerjasama siswa dalam kelompok berlangsung secara tim, tidak lagi secara individual. Siswa mampu berkomunikasi dalam menerima dan menyampaikan pendapat, baik sesama siswa maupun dengan guru, tapi masih harus disuruh olah guru. Terlihat juga peningkatan jumlah siswa yang berani mengemukakan pendapat.

2) Aspek Penilaian Psikomotor

Pada pertemuan kedua siklus II, siswa sudah terlihat semakin terampil menggunakan alat-alat dan lebih tekun dalam bekerja. Siswa juga telah mampu memanfaatkan waktu dengan efektif atas instruksi guru. Siswa sudah mampu terlihat saling bekerjasama dalam kelompok.

4. Refleksi

Setelah dilakukan tindakan pada siklus II melalui dua kali pertemuan, terlihat peningkatan pada semua aspek pengamatan yang dilakukan, semua hambatan yang ditemukan pada pertemuan siklus sebelumnya dapat diperbaiki dan diperoleh hasil yang memuaskan. Terjadi peningkatan pada aktivitas guru, aktivitas siswa, dan aspek pelaksanaan pembelajaran.

Guru telah melaksanakan proses pembelajaran dengan penerapan metode discovery dengan baik. Siswa telah mengalami kemajuan dalam hal penilaian aspek afektif dan psikomotor. Hasil belajar (aspek kognitif) siswa juga mengalami peningkatan.
Jika dipersentasekan maka sebanyak $91,66 \%$ siswa yang dinyatakan tuntas dan hanya $8,34 \%$ yang dinyatakan tidak tuntas. Berdasarkan perbandingan persen-tase di atas maka penelitian dinyatakan berhasil dan guru sudah berhasil dalam usaha penggunaan metode discovery untuk meningkatkan hasil belajar IPA di kelas IV SD Negeri 28 Air Tawar Timur Kecamatan Padang Utara.

\section{PEMBAHASAN}

1. Pembahasan Siklus I

Pelaksanaan pembelajaran dengan penerapan metode discovery pada siklus I dilaksanakan di kelas IV SD Negeri 28 Air Tawar Timur pada pembelajaran IPA dengan materi pokok sifat dan perubahan wujud benda. Pembelajaran dengan menggunakan metode discovery bukanlah kegiatan memindahkan pengetahuan dari guru ke peserta didik, melainkan suatu kegiatan yang memungkinkan peserta didik menemukan dan memecahkan sendiri permasalahan melalui kegiatan yang dilakukan. Dari serangkaian kegiatan yang dilakukan oleh peneliti dalam menyajikan materi gaya mengubah gerak dan bentuk suatu benda dengan menggunakan metode discovery, maka didapat hasil ratarata kelas diperoleh pada siklus I sebesar $52 \%$.

2. Pembahasan Siklus II

Tahap pelaksanaan pembelajaran pada siklus II ini sama dengan langkah-langkah pada siklus I. Perubahan dilakukan pada saat memberikan bimbingan dalam melakukan kerja kelompok. Pada siklus I guru memberikan bimbingan banyak secara klasikal, namun pada siklus II bimbingan diberikan kepada masing-masing kelompok dengan cara mengunjungi kelompok yang sedang berdiskusi. Pada siklus II ini peserta 
didik sudah terbiasa bekerja sama dalam kelompok.

Jika dipersentasekan maka sebanyak $91,66 \%$ siswa dinyata-kan tuntas dan hanya $8,34 \%$ siswa yang dinyatakan tidak tuntas. Berdasarkan perbandingan persen-tase di atas, maka penelitian ini dinyatakan berhasil.

\section{SIMPULAN DAN SARAN \\ Simpulan}

Berdasarkan hasil observasi dan refleksi selama penelitian ini berlangsung dapat disimpulkan bahwa terjadi peningkatan hasil belajar IPA secara signifikan dengan penerapan metode discovery pada siswa kelas IV SD Negeri 28 Air Tawar Timur Kecamatan Padang Utara pada semua spek yang di amati, antara lain hasil belajar aspek afektif, psikomotor, dan juga kognitif.

\section{Saran}

Saran yang dapat diberikan dalam penelitian ini adalah: a) disarankan kepada Guru hendaknya dapat menerapkan metode discovery dalam pembelajaran IPA di sekolah dasar, dan b) disarankan kepada Kepala Sekolah agar dapat berupaya meningkatkan sarana dan prasarana yang menunjang kualitas pembelajaran IPA di sekolah dasar.

\section{DAFTAR PUSTAKA}

Abu Ahmadi, Joko Tri Prasetyo. (2005). Strategi Pembelajaran. Bandung: Pustaka Setia
Depdiknas. (2004). Kurikulum Berbasis Kompetensi. Jakarta: Dirjen Pendidikan Tinggi

Kemmis, S. dan Taggart. 1990. The Action Research Planner. Victoria: Deakin University.

Maslichah asy'ari. (2006). Penerapan Pendekatan Sains-Teknologi-Masyarakat Dalam Pembelajarn Sains Di Sekolah Dasar. Yogyakarta: Pustaka Setia

Mulyasa, E. 2007. Kurikulum Berbasis Kompetensi, Konsep, Karakte-ristik, dan Implementasi. Bandung: Remaja Rosdakarya.

Oemar Hamalik. (1997). Media Pendidikan. Jakarta: PT Bumi Aksara

Oemar Hamalik. (2004). Pendidikan Guru BerdasarkanPendekatan Kompetensi. Jakarta: PT Bumi Aksara

Roestiyah N.K. (2001). Strategi Pembelajaran. Jakarta: PT Rineka Cipta

Rohani. (2008). Penerapan Metode Discovery http://dadhar.blogspot.com/!757DFC794 2!GFD435.html. Online tanggal 3 maret 2009

Soemarno. (1994). Design Penelitian TindakanI. Yogyakarta: Pustaka Setia 